\title{
PENERAPAN LAPORAN KEUANGAN BERBASIS SAK- EMKM TERHADAP KUALITAS LAPORAN KEUANGAN PADA UMKM KAMPUNG KUE DI RUNGKUT SURABAYA
}

\author{
Hendy Widiastoeti ${ }^{1}$, Chatarina Agustin Endah Sari ${ }^{2}$ \\ ${ }^{1}$ Program Studi Akuntanasi, Universitas 17 Agustus 1945 Surabaya \\ hendi@untag-sby.ac.id \\ ${ }^{2}$ Program Studi Akuntanasi, Universitas 17 Agustus 1945 Surabaya \\ sarichatarina36@gmail.com
}

\section{Info Artikel (11 pt) \\ Diterima Januari , 2020 \\ Direvisi Februari 20, 2020 \\ Dipubikasi Maret 20, 2020}

\section{Kata Kunci:}

Laporan Keuangan, SAK EMKM, Kualitas Laporan Keuangan

\section{Abstrak}

Penelitian ini bertujuan untuk mengetahui cara penyusunan laporan keuangan UMKM dan untuk mengetahui kendala yang dihadapi para pelaku UMKM dalam rangka Penerapan SAK EMKM per 1 Januari. Penelitian ini menggunakan penelitian kualitatif deskriptif dengan pengumpulan data, analisis data, serta diakhiri dengan kesimpulan, dengan jenis penelitian studi kasus. Jenis data yang digunakan adalah data primer. Data dikumpulkan dengan wawancara, dokumentasi dan obervasi. Hasil penelitian menunjukkan bahwa (1) Prosesn pencatatan dan penyusunan laporan keuangan yang dilakukan tiap-tiap UMKM masih sederhana, (2) Kendala yang dialami oleh maisng-masing UMKM yaitu Sumber Daya Manusia (SDM) dalam mengelola keuangan, tingkat kompetensi dan ruang lingkup organisasi yang kecil. (3) penyusunan laporan keuangan yang sesuai SAK EMKM pada UMKM Kampung Kue dintaranya UD. Pawon Kue, UD. Putri, Dieva Cake, Aish Cake terdiri dari laporan posisi keuangan sesuai SAK EMKM, Laporan laba rugi dan Catatan atas laporan keuangan.

\section{Abstract}

This study aims to find out how to prepare MSME financial reports and to find out the obstacles 
faced by MSME actors in the framework of implementing SAK EMKM as of 1 January. This research uses descriptive qualitative research with data collection, data analysis, and concludes with a conclusion, with the type of case study research. The type of data used is primary data. Data collected by interview, documentation and observation. The results showed that (1) the process of recording and compiling financial statements carried out by each MSME was still simple, (2) the constraints experienced by each MSME were Human Resources (HR) in managing finances, the level of competence and scope of the organization. the small one. (3) preparation of financial statements in accordance with SAK EMKM at UMKM Kampung Kue dintarnya UD. Pawon Kue, UD. Putri, Dieva Cake, Aish Cake consists of financial position reports in accordance with SAK EMKM, income statement and notes to financial statements.

\section{I.PENDAHULUAN}

Usaha Mikro, Kecil dan Menengah atau dikenal dengan sebutan UMKM merupakan jenis usaha yang terbukti mampu memberikan kontribusi serta peran yang nyata pada sektor perekonomian. UMKM bahkan dianggap sebagai pokok utama alternatif pada perekonomian di Indonesia, karakteristiknya yang kuat, dinamis dan efisien mampu mendorong pembangunan ekonomi bangsa. Pemanfaatan UMKM terbukti mampu memaksimalkan potensi sumber daya yang ada, karena UMKM biasanya bergerak dalam sektor industri lokal dan tidak bergantung pada impor, dengan hasil yang beragam dan unik sehingga mampu bersaing di pasar ekspor. Perekonomian Indonesia dapat menunjukkan kemampuannya dalam memiliki fundamental yang kuat, apabila koperasi dan UMKM dapat menjadi pelaku utama dalam perekonomian nasional yang produktif serta memiliki daya saing (Alhusain, 2014 Hal : 2). Data dari Kementrian KUKM Indonesia pada Tuti \& Dwijayanti (2014) menyatakan bahwa UMKM mampu memberikan kontribusi sebesar 56\% untuk PDB (Produk Domestik Bruto), dengan jumlah UKM yang mencapai 56,6\% juta serta 99,8\% dari UMKM mampu menyerap 7\% tenaga kerja di Indonesia pada tahun 2013. Kontribusi UMKM yang besar terhadap perekonomian juga terjadi di banyak Negara, seperti yang dikutip dari Baas dan Schrooten (2006) menyatakan bahwa jumlah UKM di Negara maju mencapai 90\% dari keseluruhan usaha serta mampuu menyerap tenaga kerja 2/3. Dari jumlah pengangguran yang terdapat di negara-negara tersebut. Kelebihan lai dari UMKM adalah dalam menciptakan produk-produk yang lebih bermanfaat dan dapat dinikmati oleh masyarakat secara 
luas. Selain itu, peran strategis dari UMKM sebagai alternatif pengamanan masyarakat terhadap ancaman krisis dan turbulensi ekonomi (Probosari, 2014).

Informasi akuntansi sangat bermanfaat bagi UMKM, karena merupakan alat yang digunakan oleh pengguna informasi untuk pengambilan keputusan (Nicholls dan Holmes, 1998) dalam (Wahyudi, 2009). Informasi akuntansi dapat digunakan untuk mengukur dan mengkomunikasikan informasi keuangan perusahaan yang sangat diperlukan oleh pihak manajemen dalam merumuskan berbagai keputusan untuk memecahkan permasalahan yang dihadapi. UMKM seharusnya menyusun laporan keuangan sesuai dengan kondisi usaha agar pengguna dapat membaca dan mengerti kinerja dan posisi keuangan. Oleh karena itu, pembuat laporan keuangan harus lebih diperhatikan dari segi pengetahuan dan pengalamannya dalam menyusun laporan keuangan. Jika pengelola keuangan merasa tidak mampu dan tidak mempunyai pengalaman dalam mengelola keuangan, sebaiknya menyewa jasa akuntan agar mampu mempunyai laporan keuangan yang jelas (Ediraras, $2010 \mathrm{Hal}$ : 152-158).

Pelaku UMKM di Indonesia masih banyak yang tidak membuat dan memakai informasi akuntansi dalam pengelolaan usahanya. Alhasil, jika ditanya tentang sejumlah aset yang dimiliki mereka tidak bisa mengungkapkannya. Menurut Idrus dalam Hanum (2013) adalah seorang manajer klinik usaha kecil dan koperasi Ikatan Akuntansi Indonesia (IAI) menyatakan bahwa para pengusaha kecil tidak memiliki pengetahuan akuntansi dan banyak diantara mereka yang belum memahami pentingnya pencatatan dan pembukuan bagi kelangsungan usaha mereka dan keberhasilan usaha. Minimnya pengetahuan sumber daya manusia (SDM) tentang proses akuntansi membuat mereka merasa kesulitan dalam melakukan pencatatan terhadap apa yang terjadi di perusahaan.

\section{Rumusan Permasalahan}

Berdasarkan latar belakang yang telah diuraikan diatas maka penulis yang membuat rumusan masalah dalam penelitian ini ialah :

1) Bagaimana penyusunan laporan keuangan UMKM dalam menerapkan SAK EMKM tahun 2018?

2) Apa saja kendala-kendala yang dihadapi UMKM dalam penerapan SAK EMKM tahun 2018?

\section{Tujuan Penelitian}

Sesuai dengan perumusan masalah diatas, maka tujuan penelitian untuk memperoleh bukti faktual atau ontetik mengenai :

a) Untuk mengetahui cara penyusunan Laporan keuangan UMKM dalam rangka Penerapan SAK EMKM per 1 Januari 2018.

b) Untuk mengetahui kendala yang dihadapi para pelaku UMKM dan memberikan solutif dalam rangka Penerapan SAK EMKM per 1 Januari 2018.

\section{II.KAJIAN PUSTAKA}




\section{Akuntansi}

Pesatnya pertumbuhan ekonomi dan semakin kompleksnya masalah perusahaan yang didorong kemajuan teknologi yang semakin hari semakin berkembang. Bertambahnya peraturan pemerintah terhadap kegiatan yang dilakukan perusahaan, maka para perusahaan banyak menggunakan ilmu akuntansi dalam menjalankan usahanya untuk memperlancar kegiatan usaha mereka. Tidak hanya perusahaan, Usaha Mikro Kecil Menengah (UMKM) pun sudah banyak menerapkan ilmu akuntansi, para ahli ekonomi dan akuntansi telah mendefinisikan akuntansi dengan berbagai perbedaan menurut pendapat mereka, berikut ini merupakan pengertian akuntansi menurut para ahli "Menurut Rudianto (2012 : 4) "akuntansi adalah sistem informasi yang menghasilkan informasi keuangan kepada pihak - pihak yang berkepentingan mengenai aktivitas ekonomi dan kondisi atau perusahaan". Menurut Harrison et al (2011 dalam Sirait, 2014 : 2) akuntansi (Accounting) adalah "bahasa bisnis dan sistem informasi yang mengukur aktivitas, memproses data menjadi laporan serta mengkomunikasikan hasilnya bagi pengambilan keputusan".

\section{Akuntansi Perusahaan Manufaktur}

"Perusahaan Manufaktur adalah perusahaan yang kegiatan dan aktivitasnya mengolah bahan mentah menjadi barang setengah jadi atau barang jadi" (Sujarweni, 2015 : 15). Menurut sifat operasinya, perusahaan dibagi menjadi tiga yakni perusahaan jasa, dagang dan manufaktur. Perusahaan jasa hanya memberikan jasa tetapi ditunjang dengan adanya perusahaan dagang memiliki persediaan yang dinamakan dengan persediaan barang dagangan. Persediaan ini memiliki perusahaan dengan cara membeli dan menjualnya kembali tanpa mengolah menjadi barang baru. Sedangkan perusahaan manufaktur adalah perusahaan yang megolah persediaan barang bahan baku menjad barang jadi.

Perbedaan pengelolaan persediaan tersebut menjadi perbedaan utama dalam perlakuan akuntansi antara perusahaan jasa, dagang, dan manufaktur. Untuk perusahaan jasa karena tidak memiliki persediaan maka tidak perlu perlakuan akuntansi untuk persediaan, untuk perusahaan dagang karena memiliki persediaan barang dagangan maka perlu adanya perlakuan akuntansi untuk persediaan barang dagangan. Demikian pula dengan perusahaan manufaktur, memerlukan perlakuan akuntansi untuk persediaan mulai dari persediaan bahan baku, persediaan barang dalam proses dan persediaan barang jadi.

\section{UMKM}

Usaha Kecil Menengah atau sering disingkat dengan UMKM adalah salah satu bagian penting dari perekonomian suatu negara maupun daerah, begitu juga dengan negara Indonesia. Usaha Kecil Menengah merupakan kegiatan ekonomi rakyat yang berskala kecil dan menengah serta perlu dilindungi untuk mencegah dari persaingan usaha yang tidak sehat. UMKM di Indonesia memberikan 
kontribusi yang sangat signifikan terutama ketika krisis yang dialami pada periode 1998 sampai dengan periode 2000. UMKM di Indonesia telah dapat perhatian dan pembinaan dari pemerintah dengan membuat portofolio kementrian yaitu Menteri Koperasi dan UMKM.

Menurut Rudianto (2012 : 3) terdapat tiga bidang yang dapat dijelaskan sebagai berikut :

1. Perusahaan jasa, yaitu perusahaan yang produknya adalah bersifat non fisik yang dimana kegiatannya menyediakan jasa untuk pelanggan.

2. Perusahaan dagang, yaitu perusahaan yang membeli barang dari perusahaan lain dan menjualnya kepada pihak yang membutuhkan konsumen.

3. Perusahaan manufaktur, yaitu perusahaan yang membeli bahan baku, kemudian mengolahnya hingga menjadi produk jad yang siap dijual dan dipakai.

Menurut UU No. 20 Tahun 2008, pengertian Usaha Mikro Kecil Menengah maupun usaha besar yaitu : Usaha Mikro merupakan usaha produktif milik orang perorangan dan / atau badan usaha perorangan yang memenuhi kriteria Usaha Mikro sebagaimana diatur dalam Undang - Undang ini.

\section{Laporan Keuangan Berdasarkan SAK EMKM}

Menurut IAI dalam SAK EMKM (2018 : 42) entitas yang termasuk memenuhi seluruh kriteria maupun karakteristik sebagai berikut :

a) Entitas yang tidak memiliki akuntabilitas publik signifikan dan menerbitkan laporan keuangan untuk tujuan umum bagi pengguna eksternal.

Bukan merupakan anak perusahaan atau bukan cabang perusahaan yang dimiliki, dikuasai, atau menjadi bagian baik langsung maupun tidak langsung dari usaha menengah atau usaha besar (bukan merupakan entitas anak dan entitas asosiasi) sebagaimaa dijelaskan di Pasal 1 UU No 20 Tahun 2008.

Laporan keuangan merupakan proses akuntansi yang dapat digunakan untuk mengkomunikasikan data atau angka keuangan serta aktivitas perusahaan kepada pihak yang berkepentingan. Maka dari itu laporan keuangan mempunyai tujuan menyajikan secara wajar sesuai dengan prinsip akuntansi yang berlaku umum mengenai posisi keuangan dan hasil usaha. Hery (2012:2) 


\section{III.METODE PENELITIAN}

\section{Sumber Data}

Sumber data yang diperoleh dan digunakan dalam penelitian ini adalah data primer. Data primer merupakan data yang dikumpulkan berdasarkan interaksi langsung antara pengumpul dan sumber data. Data primer disini merupakan data data yang diperoleh dari hasil pertanyaan melalui wawancara yang diberikan kepada pemilik sekaligus pelaku dan pengurus UMKM.

\section{Pengolahan Data}

Proses pengolahan data menjelaskan prosedur pengolahan analis data sesuai dengan pendekatan yang dilakukan. Karena penelitian ini menggunakan metode kualitatif, maka metode pengolahan data dilakukan dengan menguraikan dalam bentuk kalimat teratur, runtun, logis, tidak tumpang tindih, dan efektif sehingga memudahkan pemahaman dan interpretasi data.

\section{Metode Analisis Data}

Analisis data yaitu mengelompokkan data dengan mempelajari data kemudian memilah data - data yang telah dikumpulkan untuk mencari data - data penting mana yang harus dipelajari. Analisa data adalah proses merinci usaha secara formal untuk menemukan tema dan merumuskan ide seperti yang disarankan oleh data dan sebagai usaha untuk memberikan bantuan pada tema dan ide itu.Adapun hal yang sama, dalam sebuah penelitian ada beberapa alternatif analisis data yang dapat dipergunakan yaitu antara lain : induktif kualitatif, deskriptif kualitatif yaitu analisis yang menggambarkan keadaan atau status fenomena dalam kata - kata atau kalimat, kemudian dipisahkan menurut kategori untuk memperoleh kesimpulan.

\section{IV.HASIL DAN PEMBAHASAN}

UMKM (Usaha Mikro, Kecil dan Menengah) telah banyak mendorong kemajuan perekonomian secara nasional. Namun dalam perihal perekonomian, tidak semua UMKM melakukan pencatatan keuangan atas kinerja usahanya. Dalam UMKM Kampung Kue terdapat 65 pelaku usaha UMKM, namun hampir semua pelaku UMKM di Kampung Kue ini tidak melakukan pencatatan keuangan yang rutin. Dalam 4 dari 7 UMKM yang menjadi sampel dalam penelitian ini, sudah mempunyai legalitas dan sudah berbadan hukum, akan tetapi dalam kinerja keuangan usahanya, masing-maisng pelaku UMKM jarang sekali dan hampir tidak pernah membuat laporan keuangan. Berikut ini terdapat UD. Pawon Kue, UD. Putri, Dieva Cake, dan Aish Cake yang merupakan sampel dalam penelitian ini dan juga berikut ini pemaparan dari penerapan laporan keuangan sesuai pencatatan keuangan yang dilakukan masing-masing pelaku UMKM (secara sederhana) dan juga penerapan pencatatan laporan keuangan yang sudah sesuai standar yaitu berbasis SAK EMKM yang sudah aktif dan diterbitkan per 1 Januari 
2018.

\section{UD. PAWON KUE \\ CATATAN ATAS LAPORAN KEUANGAN \\ 31 DESEMBER 2019}

\section{UMUM}

UD. Pawon Kue didirikan di Kampung Kue, Desa Kali Rungkut, Kecamatan Rungkut, Surabaya sejak tahun 2013. UD. Pawon Kue sudah memiliki legalitas dengan dibuktikan sudah terdaftarnya UD. Pawon Kue Pada Dinas Perindustrian dan Perdagangan dan memiliki Surat Izin Usaha, Uji Nutrisi, HALAL, dan barcode produk. UD. Pawon Kue bergerak dalam bidang usaha manufaktur. UD. Pawon Kue memenuhi kriteria sebagai Entitas, Mikro, Kecil, dan Menengah sesuai UU Nomor 20 Tahun 2008.

\section{IKHTISAR KEBIJAKAN AKUNTANSI PENTING}

a. Piutang Usaha

Piutang usaha disajikan sebesar jumlah tagihan

b. Persediaan

Biaya persediaan bahan baku meliputi biaya pembelian dan biaya angkut pembelian. Biaya konversi meliputi biaya tenaga kerja langsung dan overhead. Overhead tetap dialokasikan ke biaya konversi berdasarkan kapasitas produksi normal. Overhead variabel dialokasikan pada unit produksi berdasarkan penggunaan aktual fasilitas produksi. Entitas menggunakan rumus biaya persediaan ratarata.

c. Aset Tetap

Aset tetap dicatat sebesar biaya perolehannya jika aset tersebut dimiliki secara hukum oleh entitas. Aset tetap disusutkan menggunakan metode garis lurus tanpa nilai residu.

3. KAS

Kas kecil Surabaya - Rupiah

Rp 1.000.000,00

\section{PIUTANG USAHA}

Park \& Ride

CTH Dinas Koperasi

Hero Market

Centra UKM Siola
Rp 2.500.000,00

Rp 5.000.000,00

Rp 9.000.000,00

Rp 7.500.000,00 
Centra UKM Merr

Park \& Ride Pelindo

Toko Oleh-oleh Bahira

Patata Surabaya

Atap Surabaya

Brownies Amanda Jl. Kutai

Brownies Amanda Jl. Barata

Brownies Amanda Jl. Bali

Jumlah

\section{BEBAN DIBAYAR DI MUKA}

Sewa Rumah

Jumlah
Rp 7.500.000,00

Rp 2.500.000,00

Rp 4.500.000,00

Rp 12.150.000,00

Rp 10.125.000,00

Rp 2.250.000,00

Rp 2.250.000,00

Rp 2.250.000,00

Rp 67.525.000,00

\section{9}

Rp 12.000.000,00

Rp 12.000.000,00

\section{UTANG BANK}

Pada tanggal 23 September 2018, UD. Pawon Kue memperoleh pinjaman Kredit Modal Kerja (KMK) dari PT Bank BRI dengan kredit Rp 15.000.000,00 suku bunga efektif 0\% per tahun dengan jatuh tempo berakhir tanggal 23 September 2020. Pinjaman dijamin dengan persediaan dan kendaraan yang dimiliki UD. Pawon Kue.

\section{SALDO LABA}

Saldo laba merupakan akumulasi selisih penghasilan dan beban, setelah dikurangkan dengan distribusi kepada pemilik. Saldo laba UD. Pawon Kue Rp 185.641.750

\section{PENDAPATAN PENJUALAN}

Penjualan

Jumlah

\section{BEBAN LAIN-LAIN}

Bunga pinjaman

Lain-lain

Jumlah

\section{9}

Rp 547.800.000,00

Rp 547.800.000,00 


\section{BEBAN PAJAK PENGHASILAN}

\section{9}

Pajak penghasilan

\section{UD. PAWON KUE \\ CATATAN ATAS LAPORAN KEUANGAN \\ 31 DESEMBER 2019}

\section{UMUM}

UD. Pawon Kue didirikan di Kampung Kue, Desa Kali Rungkut, Kecamatan Rungkut, Surabaya sejak tahun 2013. UD. Pawon Kue sudah memiliki legalitas dengan dibuktikan sudah terdaftarnya UD. Pawon Kue Pada Dinas Perindustrian dan Perdagangan dan memiliki Surat Izin Usaha, Uji Nutrisi, HALAL, dan barcode produk. UD. Pawon Kue bergerak dalam bidang usaha manufaktur. UD. Pawon Kue memenuhi kriteria sebagai Entitas, Mikro, Kecil, dan Menengah sesuai UU Nomor 20 Tahun 2008.

\section{IKHTISAR KEBIJAKAN AKUNTANSI PENTING}

d. Piutang Usaha

Piutang usaha disajikan sebesar jumlah tagihan

e. Persediaan

Biaya persediaan bahan baku meliputi biaya pembelian dan biaya angkut pembelian. Biaya konversi meliputi biaya tenaga kerja langsung dan overhead. Overhead tetap dialokasikan ke biaya konversi berdasarkan kapasitas produksi normal. Overhead variabel dialokasikan pada unit produksi berdasarkan penggunaan aktual fasilitas produksi. Entitas menggunakan rumus biaya persediaan rata-rata.

f. Aset Tetap

Aset tetap dicatat sebesar biaya perolehannya jika aset tersebut dimiliki secara hukum oleh entitas. Aset tetap disusutkan menggunakan metode garis lurus tanpa nilai residu.

\section{KAS}

Kas kecil Surabaya - Rupiah

14. PIUTANG USAHA

Park \& Ride

\section{9}

Rp 1.000.000,00 
CTH Dinas Koperasi

Hero Market

Centra UKM Siola

Centra UKM Merr

Park \& Ride Pelindo

Toko Oleh-oleh Bahira

Patata Surabaya

Atap Surabaya

Brownies Amanda Jl. Kutai

Brownies Amanda Jl. Barata

Brownies Amanda Jl. Bali

Jumlah
Rp 5.000.000,00

Rp 9.000.000,00

Rp 7.500.000,00

Rp 7.500.000,00

Rp 2.500.000,00

Rp 4.500.000,00

Rp 12.150.000,00

$\mathrm{Rp} 10.125 .000,00$

Rp 2.250.000,00

Rp 2.250.000,00

Rp 2.250.000,00

Rp 67.525.000,00

\section{BEBAN DIBAYAR DI}

\section{MUKA}

Sewa Rumah

Jumlah

\section{9}

Rp 12.000.000,00

Rp 12.000.000,00

\section{UTANG BANK}

Pada tanggal 23 September 2018, UD. Pawon Kue memperoleh pinjaman Kredit Modal Kerja (KMK) dari PT Bank BRI dengan kredit Rp 15.000.000,00 suku bunga efektif 0\% per tahun dengan jatuh tempo berakhir tanggal 23 September 2020. Pinjaman dijamin dengan persediaan dan kendaraan yang dimiliki UD. Pawon Kue.

\section{SALDO LABA}

Saldo laba merupakan akumulasi selisih penghasilan dan beban, setelah dikurangkan dengan distribusi kepada pemilik. Saldo laba UD. Pawon Kue Rp 185.641.750

\section{PENDAPATAN}

PENJUALAN

Penjualan

Jumlah
2019

Rp 547.800.000,00

Rp 547.800.000,00

\section{BEBAN LAIN-LAIN}

Bunga pinjaman

Lain-lain

$0 \%$

Jumlah 
20. BEBAN

PENGHASILAN

Pajak penghasilan
PAJAK

2019

Usaha Mikro, Kecil, dan Menengah atau dikenal dengan sebutan UMKM merupakan jenis usaha yang terbukti mampu memberikan kontribusi serta peran yang nyata pada sektor perekonomian. Pemanfaatan UMKM terbukti mampu memaksimalkan potensi sumber daya yang ada, karena UMKM biasanya bergerak dalam sektor industri lokal dan tidak bergantung pada impor, dengan hasil yang beragam dan unik sehingga mampu bersaing di pasar ekspor. UMKM di Indonesia sudah mulai banyak berkembang, khususnya di Surabaya Kota Pahlawan yang memiliki daerah sektor perindustrian. Dimana dengan adanya sektor perindustrian maka penduduk di sekitarnya juga semakin meningkat. Akan tetapi penduduk di sekitar sektor perindustrian tersebut tidak hanya bekerja di pabrik-pabrik sekitar melainkan juga mereka membuka lapangan pekerjaan bagi lingkungan sekitar juga.

Seperti di Kampung Kue Surabaya yang letaknya ada di Rungkut Lor Gg II ini, banyak sekali terdapat usaha-usaha kecil yang dibuat oleh ibu-ibu yang suaminya rata-rata bekerja di pabrik sekitar. Dengan tidak hanya menggantungkan pendapatan pada kepala keluarga maka ibu-ibu di kampung kue ini juga berwirausaha membuat kue. Di kampung kue ini terdapat sekitar kurang lebih 65 UMKM yang ada di dalamnya, namun dalam proses produksi dan jual beli yang sudah dilakukan sejak didirikannya kampung kue ini. Hampir seluruh UMKM di Kampung Kue ini tidak membuat laporan keuangan secara periodik, dimana ketika UMKM tidak membuat laporan keuangan, maka pemilik UMKM sendiri tidak dapat mengetahui berapa sebenarnya aset yang dimiliki dan berapa keuntungan sesungguhnya yang telah diperoleh tiap periodiknya.

\section{V.KESIMPULAN DAN SARAN KESIMPULAN}

Berdasarkan pembahasan yang telah dijelaskan dalam bab sebelumnya maka dapat diperoleh kesimpulan bahwa pelaku UMKM hanya menggunakan pembukuan atau catatan sederhana untuk mencatat keuangan usaha dan hampir jarang sekali pencatatan yang dilakukan dikerjakan secara rutin oleh pelaku UMKM sehingga pencatatannya dan bukti transaksi yang ada tidak lengkap. Proses penyusunan laporan keuanga para pelaku UMKM di Kampung Kue juga disusun hanya berdasarkan pengetahuan dari pemilik yang hanya memahami akuntansi secara sederhana. Alasan para UMKM hampir tidak pernah menyusun laporan keuangan karena akuntansi dan pembukuan dianggap rumit dan sulit untuk diterapkan serta keterbatasan pemahaman dan keterampilan dalam 
menyusun laporan keuangan. Selain itu ada beberapa kendala yang dialami oleh para pelaku UMKM dalam menyusun laporan keuangan berbasis SAK EMKM yaitu, faktor Sumber Daya Manusia (SDM) dalam keuangan, tingkat kompetensi dan ruang lingkup organisasi yang kecil. Oleh karena itu, peneliti membantu memberikan penerapan dengan metode yang sederhana yang dapat digunakan dalam menyusun laporan keuangan yaitu penyusunan laporan keuangan melalui persamaan dasar akuntansi yang di susun berdasarkan dan sesuai dengan SAK EMKM yang telah diterbitkan IAI per Januari 2018 guna untuk membantu pelaku UMKM dalam menyusun laporan keuangan usahanya. Persamaan dasar akuntansi yang telah sesuai dengan SAK EMKM ini dapat disesuaikan dengan kebutuhan para pelaku UMKM, dan hasil penelitian menunjukkan bahwa para pelaku UMKM merasa terbantu dengan adanya penerapan laporan keuangan berbasis SAK EMKM. Penyusunan laporan keuangan berbasis SAK EMKM pada usahausaha yang dilakukan pelaku UMKM di Kampung Kue terdiri dari :

a) Laporan posisi keuangan yang mencerminkan keadaan usaha sebenarnya sehingga pemilik dapat mengambil keputusan keuangan yang tepat.

b) Laporan laba rugi yang dibuat oleh sebuah entitas dapat mencerminkan dan memberikan informasi mengenai berapa keuntungan atau kerugian sebuah entitas.

c) Catatan atas laporan keuangan yang mengungkapkan penjelasan lebih lanjut mengenai akun-akun yang terdapat pada laporan laba rugi dan laporan posisi keuangan (neraca).

\section{SARAN}

Adapun saran-saran yang dapat diberikan terkait penyusunan laporan keuangan sesuai SAK EMKM pada usaha UD. Pawon Kue, UD. Putri, Dieva Cake, dan Aish Cake dalam Kampung Kue Rungkut Surabaya adalah sebagai berikut :

1) Perkembangan Usaha Mikro, Kecil, dan Menengah (UMKM) akan lebih baik lagi apabila jika ditunjang dengan pencatatan keuangan yang baik. Jadi para pelaku UMKM lebih baik mulai menerapkan pencatatan laporan keuangan sesuai dengan standar yang berlaku yaitu SAK EMKM sebagai acuan dalam menyusun laporan keuangan.

2) Perlu adanya pengawasan, aturan dan pendampingan dalam menyusun laporan keuangan agar para pelaku UMKM dapat menyusun laporan keuangan sesuai standar yang telah ditetapkan yaitu SAK EMKM yang sudah diterbitkan per 1 Januari 2018.

3) Penelitian selanjutnya diharapkan dapat menemukan metode penentuan HPP (Harga Pokok Penjualan) bagi UMKM yang bergerak di bidang produksi.

Untuk peneliti berikutnya yang hendak meneliti mengenai penerapan 
lapooran keuangan diharapkan melakukan penelitian di jenis usaha yang berbeda sehingga dapat ditemukan hasil penelitian lain yang dapat menunjang penelitianpenelitian berikutnya.

\section{DAFTAR PUSTAKA}

Adiningsih, Sri et al. (2001). "Perangkat dan Teknik Analisis Investasi di Pasar Modal Indonesia”. Edisi Revisi Pertama. PT. BEJ. Jakarta.

Alhusain, Achmad Sani. (2014). "Analisa Kebijakan Permodalan dalam Mendukung Pengembangan Usaha Mikro Kecil dan Menengah (Studi Kasus Provinsi Bali dan Sulawesi Utara)". Kajian Vol 14 No.4 Hal : 2.

Almaida, Asty dan Sony Warsono (2007). "Mekanisme Alih Pengetahuan Anggota Tim Manajemen Atas dan Eksekutif STI: Menuju Keselarasan Sistem Informasi Strategik". SNA, 10, 26-28 Juli 2007

Andriani, L et al. (2014). "Analisis Penerapan Pencatatan Keuangan Berbasis SAK ETAP Pada Usaha Mikro Kecil Menengah (UMKM) (Sebuah Studi Intrepetatif Pada Peggy Salon)". Universitas Pendidikan Genesha. Volume 2,No.1 Hal : 5.

Baas, Timo \& Mechthild Schrooten. (2006). "Relationship Banking and SMEs: A Theoretical Analysis. Small Business Economic". Vol. 27.

Creswell, J.W. (2014). Research Design Pendekatan Kualitatif, Kuantitatif, dan Mixed. Edisi : 4. Yogyakarta: Pustaka Pelajar.

Ediraras, Dharma T. (2010). “Akuntansi dan Kinerja UKM.” Jurnal Ekonomi dan Bisnis. 2(XV). Hlm. 152-158.

Hanum, Hashemi Rodhian dan Zulaikha. (2013). "Pengaruh Karakteristik Corporate Governance terhadap Effective Tax Rate". Diponegoro Journal of Accounting ISSN (Online): 2337-3806 Volume 2, Nomor 2, Tahun 2013 Halaman 1-10. 
Hermawan, S. (2013). Akuntansi Perusahaan Manufaktur. Edisi 1. Yogyakarta: Graha Ilmu.

Hery. (2012). Akuntansi Keuangan Menengah 1. Edisi 1. Jakarta: Bumi Aksara.

Horrison Jr., Walter T., et al. (2012). Akuntansi Keuangan IFRS Edisi Kedelapan Jilid 1. Jakarta: Erlangga.

Hutagaol, R.M.N. (2012). "Penerapan Akuntansi Pada Usaha Kecil Menengah". Fakultas Bisnis Unika Widya Mandala. Volume1, No.2.

Ikatan Akuntan Indonesia. (2018). Standar Akuntansi Keuangan Entitas Mikro, Kecil, dan Menengah. Jakarta: Dewan Standar Akuntansi Keuangan Ikatan Akuntan Indonesia.

Kartikahadi, H et al. (2012). Akuntansi Keuangan Berdasarkan SAK berbasis IFRS. Jakarta: Salemba Empat.

Kurniawati, E.P et al. (2012). "Penerapan Akuntansi Pada Usaha Mikro Kecil dan Menengah (UMKM)". Informatics and Business Institute Darmajaya. Volume 10, No.2.

Nurlaila. (2018). "Penerapan Standar Akuntansi Keuangan Entitas Mikro Kecil Dan Menengah (SAK EMKM) pada Sukma Cipta Ceramic Dinoyo - Malang”. Skripsi. Malang: Universitas Islam Negeri Maulana Malik Ibrahim Malang

Purwanti, A. (2015). "Penerapan Standar Akuntansi Keuangan untuk Entitas Tanpa Akuntabilitas Publik (SAK-ETAP) Pada Usaha Kecil Menengah (UKM) Boutique Save Fashion". Skripsi. Pontianak: Fakutas Ekonomi dan Bisnis Universitas Tanjungpura.

Rudianto. (2012). Pengantar Akuntansi Konsep dan Teknik Penyusunan Laporan Keuangan Adaptasi IFRS. Jakarta: Erlangga.

Rudiantoro, R dan S.V Siregar. (2012). "Kualitas Laporan Keuangan UMKM Serta Prospek Implementasi SAK ETAP”. Universitas Indonesia. Volume 9, No.1.

Sirait, P. (2014). Pelaporan dan Laporan Keuangan. Yogyakarta: Graha Ilmu. Sodikin, S.S dan B.A Riyono. (2014). Akuntansi Pengantar 1 Edisi 9. Yogyakarta: UPP STIM YKPN.

Sugiyono. (2017). Metode Penelitian Pendidikan Pendekatan Kuantitatif, Kualitatif, dan R\&D. Bandung: Alfabeta.

Sujarweni, V.W. (2015). Akuntansi Biaya Teori dan Penerapannya. Yogyakarta: Pustaka Baru Press. 
Sumarsan, T. (2013). Akuntansi Dasar dan Aplikasi Dalam Bisnis Versi IFRS Jilid 1. Jakarta: Indeks.

Sumarsan, T. (2015). Pengantar Praktikum Akuntansi Versi IFRS Kasus dan Kertas Kerja. Jakarta: Indeks.

Surya, R.A.S. (2013). Pengantar Akuntansi Berbasis IFRS. Yogyakarta: Graha Ilmu.

Susanti, K. (2015). “Analisis Penerapan Akuntansi Pada Usaha Kecil Menengah (Studi Pada Usaha Fotocopy di Kota Pontianak)". Skripsi. Pontianak: Fakutas Ekonomi dan Bisnis Universitas Tanjungpura.

TMbooks. (2015). Sistem Informasi Akuntansi Konsep dan Penerapan. Yogyakarta: Andi.

Umar, H. (2014). Metode Penelitian Untuk Skripsi dan Tesis Bisnis. Jakarta: Rajawali Pers.

Undang-Undang No. 20 Tahun 2008 Tentang Usaha Mikro, Kecil dan Menengah.http://www.hukumonline.com/pusatdata/download/f156047/node/ $\underline{28029}, 23$ September 2016.

Wahyudi. (2009). Kepemimpinan Kepala Sekolah Dalam Organisasi Pembelajaran. Bandung: Alfabeta.

Zuwinda, R. (2011). "Tuhttp://rahmiyatizuwinda.blogspot.co.id/2011/03/tujuanlpaoran-keuangan.html. juan Laporan Keuangan”. 14 Oktober 2019 